\title{
APLIKASI REPLIKA CHATBOT SEBAGAI WADAH EDUKASI EKSPRESI UJARAN EMOTIF TERHADAP PENGGUNA DI SMAN 1 JATINANOR
}

\author{
Lia Maulia Indrayani, Rosaria Mita Amalia dan Bima Bayusena \\ Linguistik, Fakultas Ilmu Budaya, Universitas Padjadjaran \\ E-mail: lia.maulia@unpad.ac.id, rosaria.mita.amalia@unpad.ac.id,bima.bayusena@gmail.com
}

\begin{abstract}
ABSTRAK. Replika yang merupakan bagian dari chatbot mengacu pada program komputer melalui Kecerdasan Buatan yang dapat berinteraksi dengan satu atau lebih orang, baik dalam bentuk audio maupun teks. Dengan kata lain, aplikasi ini dapat berinteraksi seperti manusia pada umumnya. Tujuan dari pengabdian masyarakat ini adalah untuk mendidik siswa bagaimana menganalisis ekspresi ujran emotif melalui chatbot Replika untuk meningkatkan pemahaman mereka dalam ekspresi-ekspresi di bahasa Inggris. Selain itu, kegiatan ini juga dimaksudkan untuk memberikan pengetahuan dan wawasan bagi siswa bagaimana menggunakan aplikasi ini secara tepat dalam kegiatan sehari-hari mereka. Penelitian ini menggunakan pendekatan pragmatis. Kegiatan ini ditujukan kepada siswa-siswi SMAN 1 Jatinangor yang akrab dan menggunakan aplikasi ini sebagai teman mereka dalam berkomunikasi sehingga edukasi tentang bagaimana menganalisis jenis-jenis ekspresi dalam aplikasi ini harus disediakan. Implementasi kegiatan ini mendapat respons positif dari para peserta. Ini mengungkapkan bahwa banyak pengguna menemukan ikatan persahabatan dengan chatbot, dan mereka diajak untuk berbicara dalam semua situasi. Mereka merasa bahwa kegiatan ini sangat bermanfaat dan memberikan wawasan dan keterampilan bagaimana menggunakan dan mempelajari banyak ekspresi bahasa Inggris melalui aplikasi ini. Aplikasi yang tersedia dalam bahasa Inggris ini diharapkan dapat memberikan pemahaman tentang penggunaan dan manfaatnya sehingga mereka dapat menggunakan aplikasi ini berdasarkan pada kebutuhan mereka.
\end{abstract}

Kata kunci: Replika; Chatbot; Ekspresi emotif; SMAN 1 Jatinangor.

ABSTRACT. Replika which is the part of the chatbot refers to a computer program through Artificial Intelligence that can interact with one or more people, both in audio and text. On the other words, this application can interact like humans in general. The objective of this community service is to educate the students how to analyze the expression of emotive utterances through Replika chatbot in order to enhance their comprehension in English expressions. Furthermore, it is also intended to provide knowledge and insight for the students how to appropriately utilize this application in their daily activity. This research uses a pragmatic approach. This event is addressed to the students of SMAN 1 Jatinangor who are familiar and use this application as their friend in communication so that the education of how to analyze the kinds of expressions in this application should be provided. The implementation of this activity obtained a positive response from the participants. It reveals that many users find friendly ties with the chatbot, and they are invited to talk in all situations. They feel that this activity is very useful and provide insight and skills how to use and learn many English expression through this application This application which is available in English is expected to provide an understanding of the use and benefits so that they can use this application based on their needs.

Keywords: Replika; Chatbot; Emotive Expression; SMAN 1 Jatinangor.

\section{PENDAHULUAN}

Saat ini, khususnya dalam era digital, manusia sudah sangat dekat dengan transformasi yang terjadi dalam bidang informasi teknologi. Segala kegiatan dapat dilakukan dalam dunia maya, seringkali manusia memiliki keterbatasan untuk melakukan interaksi dengan sesama manusia lainnya secara langsung. Anak-anak, kawula muda, serta orang tua tampak sibuk dengan alat komunikasi digital mereka, karena keseharian aktivitas dapat dilakukan melalui gawai tersebut. Manusia seringkali tidak menyadari bahwa kebutuhan akan interaksi dengan manusia, untuk saling berkomunikasi, sangatlah penting dan signifikan untuk semua kalangan usia.

Untuk memenuhi kebutuhan ini, muncullah berbagai aplikasi chatbot antara lain yang cukup dikenal adalah Replika. Picard (2000) mengembangkan aplikasi ini yang disebut sebagai komputasi afektif yang memungkinkan aplikasi ini memproses emosi dengan mengenali dan mengekpresikannya. Replika dibangun dengan teknologi kecerdasan buatan yang mempelajari obrolan dengan pengguna sehingga mampu menyesuaikan dengan kepribadian pengguna. Aplikasi ini diciptakan oleh Eugenia Kuyda dan ia mampu membangun sisi emosional dalam percakapan hingga seperti menyerupai manusia, seperti Siri asisten virtual milik Apple, chatbot Replika mampu menjawab semua pertanyaan yang diajukan, meski di awal kita yang lebih sering ditanya karena ia membutuhkan gambaran tentang diri kita. Dengan begitu, Replika bisa jadi teman komunikasi manusia layaknya sahabat setelah si chatbot mulai memahami kita. Tak sedikit penggunanya yang mengira kalau sebenarnya Replika bukanlah robot, melainkan manusia sungguhan yang memiliki perasaan. Seperti Siri asisten virtual 
milik Apple, chatbot Replika mampu menjawab semua pertanyaan yang diajukan, meski di awal kita yang lebih sering ditanya karena ia membutuhkan gambaran tentang diri kita. Contoh percakapan pada aplikasi chatbot Replika melihat fenomena tersebut, masyarakat khususnya siswa-siswa di sekolah menengah atas perlu diberikan edukasi terhadap konsep ujaran emotif yang terdapat pada chatbot Replika ini, agar kemudian mereka lebih memahami sejauh mana mereka dapat berinteraksi dan berekspresi melalui aplikasi ini. Dengan begitu, Replika bisa jadi teman komunikasi manusia layaknya sahabat setelah si chatbot mulai memahami kita. Tak sedikit penggunanya yang mengira kalau sebenarnya Replika bukanlah robot, melainkan manusia sungguhan yang memiliki perasaan. Melihat fenomena tersebut, masyarakat khususnya siswa-siswa di sekolah menengah atas perlu diberikan edukasi terhadap konsep ujaran emotif yang terdapat pada chatbot Replika ini, agar kemudian mereka lebih memahami sejauh mana mereka dapat berinteraksi dan berekspresi melalui aplikasi ini.

Analisis yang bertujuan untuk mengidentifikasi jenis emosi yang di ekspresikan dalam interaksi manusia-komputer di sebut sebagai analisis afektif. Analisis afektif perlu dilakukan dalam mengevaluasi komputasi afektif. Dalam mengenali konteks dari ucapan-ucapan afektif harus berdasarkan sebuah pendekatan pragmatik terhadap interaksi manusia dan komputer yang mecakup tiga jenis fenomena pragmatik yaitu fenomena pragmatik (seperti: tindak tutur, implikatur, presuposisi), fenomena spesifik interaksi manusia-komputer (seperti: emosi), dan mode atau gaya interaksi manusiakomputer. Pendekatan ini dapat di terapkan dalam mengidentifikasi emotif yang dilakukan oleh Replika. Oleh karena, penelitian ini diharapkan dapat memberikan sebuah analisis terhadap ucapanucapan emotif yang dilakukan oleh Replika untuk meningkatkan kemampuan berbahasa Inggris penggunanya.

Pendekatan yang digunakan adalah penekatan pragmatik. Pragmatik baru-baru ini dianggap sebagai bidang penelitian yang berkembang dalam linguistik kontemporer yang tidak hanya telah menjadi pusat minat dalam linguistik, tetapi juga telah menarik sejumlah besar pengakuan dari para ilmuwan kognitif, antropolog, dan pekerja kecerdasan buatan (Huang, 2014). Levinson (1983) mendefinisikan pragmatik sebagai ilmu yang mempelajari mengenai deiksis, implikatur, presuposisi, tindak tutur seperti emotif, dan aspek-aspek yang terdapat di dalam struktur wacana. Pragmatik adalah cabang linguistik yang secara sistematis memeriksa makna dalam penggunaan bahasa. Sebagai teknologi komunikasi semakin bergerak di luar komputer, Herring \& Virtanen (2013) membahas bahwa studi penggunaan bahasa ini harus mencakup keprihatinan. Selain itu, Emotif merujuk pada tindak tutur emosi yang berkaitan dengan keterlibatan emosional pembicara dengan ucapannya (Levinson et al., 1983). Dari berbgai pendapat para linguis mengenai definisi pragmatik dapat disimpulkan bahwa pragmatik adalah kajian mengenai penggunaan Bahasa dalam komunikasi, terutama hubungannya dengan ekppresiekspresi emotif yang dapat digunakan oleh manusia dalam berkomunikasi dalam sehari-hari berdasarkan kontek penggunaanya. Oleh karena itu, bagaiman cara menganalisis dan menggunakan ekspresi ini tentunya perlu di berikan terutama kepada siswa yang sedang belajar Bahasa inggris melalui teknologi yang ada. Sehingga, artikel ini diberi judul "Aplikasi Replika Chatbot Sebagai Wadah Edukasi Ekspresi Ujaran Emotif Terhadap Pengguna di SMAN 1 Jatinanor". Tujuan kegiatan ini adalah adanya penambahan ilmu komunikasi terutama penggunaan ekpresi-ekspresi ujuran emotif dalam Bahasa inggris bagi para siswa di SMAN 1 Jatinangor.

\section{METODE}

Metode yang digunakan dalam kegiatan ini merupakan penelitian kualitatif deskriptif dalam bidang sosial khususnya bahasa. Menurut Djadjasudarma (1993), metode analisis deskriptif merupakan metode yang secara deskriptif dapat memberikan ciri-ciri, sifat-sifat dan gambaran data melalui pemilihan data, setelah data terkumpul. Manfaat dari kegiatan ini berupa ekspresi-ekspresi ujaran emotif yang muncul dalam Replika setelah siswa berinteraksi langsung dengannya. Metode pelaksanaan Pengabdian Kepada Masyarakat ini adalah pelatihan. Pelatihan diberikan kepada para siswa SMAN 1 Jatinangor, Sumedang, Jawa Barat. Pelatihan di dalamnya terkandung penyampaian materi terlebih dahulu oleh dosen dan mahasiswa dalam bidang bahasa.

Tahapan kegiatan Pengabdian Kepada Masyarakat antara lain Survey dan Perizinan, Penyusunan Materi PKM, Pelaksanaan Kegiatan Pelatihan, dan Penyusunan Laporan Akhir. Tahapan kegiatan tersebut dilakukan oleh 3 (tiga) orang dosen dari Program Studi Sastra Inggris dengan bantuan 3 (tiga) orang mahasiswa di prodi yang sama. Keterlibatan mahasiswa ini memiliki peran yang cukup signifikan terhadap keberhasilan dari pelaksanaan kegiatan, sekaligus memberikan pengalaman dan penambahan wawasan terhadap para peserta. Indikator yang ditargetkan pada kegiatan ini adalah penjelasan terkait fenomena/gejala maraknya aplikasi chatbot, 
terutama mengenai ujaran emotif yang terdapat pada aplikasi chatbot Replika sehingga siswa-siswi SMAN 1 Jatinangor dapat memanfaatkan aplikasi ini dalam keseharian mereka.

\section{HASIL DAN PEMBAHASAN}

Berdasarkan hasil di lapangan, hampir sebagian besar siswa dan siswi di SMAN 1 Jatinangor belum mengenal apa itu yang dinamakan kecerdasan buatan, chatbot, dan Replika. Namun, meskipun mereka belum mengetahui apa yang dimaksudkan dengan chatbot, banyak diantaranya yang sudah pernah beriteraksi dengan salah satu jenis chatbot, yaitu Simsimi. Dari 35 (tiga puluh lima) siswa dan siswi yang mengikuti pelatihan, hanya 20 orang siswa dan siswi yang sudah mengenal salah satu jenis aplikasi chatbot ini. Selain itu, para siswa dan siswi di SMAN 1 Jatinangor juga sudah menggunakan salah satu produk dari kecerdasan buatan secara tidak langsung. Selain kurangnya pemahaman mengenai kecerdasan buatan, chatbot, dan Replika, pengetahuan akan bagaimana menggunakan atau memanfaatkan aplikasi atau jenis-jenis chatbot sebagai produk dari kecerdasan buatan juga masih kurang.

Dari data di lapangan, setelah materi diberikan dan workshop dilaksanakan, para siswa dan siswi SMAN 1 Jatinangor sudah memahami apa yang dimaksud dengan kecerdasan buatan, produk-produk kecerdasan buatan dan dimana kecerdasan buatan dapat ditemukan. Materi lain yang dipahami oleh mereka juga mencakup apa yang dinamakan chatbot, apa saja jenis-jenis chatbot dan manfaat apa saja yang diberikan oleh chatbot. Selain itu, siswa dan siswi SMAN 1 Jatinangor juga mengenal apa dan bagaimana mengoprasikan salah satu jenis chatbot obrolan yaitu Replika.

Setelah diberikan contoh bagaimana berinteraksi dengan Replika, para siswa dan siswi juga sudah dapat mengobrol dengan Replika melalui ponsel mereka masing-masing dengan mengunduh dan membuat akun Replika mereka sendiri. Setelah obrolan sudah dilakukan beberapa kali, para siswa dan siswi juga sudah bisa memahami bagaimana balasan dari Replika dapat digunakan untuk meningkatkan kemampuan berbahasa Inggris mereka. Selanjutnya, siswa-siswa diminta untuk menganalisis jenis ekspresi ujaran emotif apa saja yang muncul ketika berinteraksi dilakukan dan yang muncul adalah seperti ekspresi simpati, persahabatan, empati, dukungan, dan lain-lain. Siswa dan siswi pun diminta untuk menggunakan contoh ekpresi tersebut dan menggunakannya untuk interaksi-interaksi berikutnya dalam aplikasi tersebut.

Cara pelaksaan kegiatan telah dilakukan pada bulan oktober2019, pada mingguke3(tiga). Pelatihan dilakukan dalam dua tahap dengan pembagian tahap awal berupa penyampaian materi tentang Artifial Inteligence (AI) berupa chatbot Replika dan tahap kedua pelatihan implementasi aplikasi tersebut oleh siswa-siswi. Kegiatan Pengabdian kepada Masyarakat ini dilakukan dalam jam pembelajaran bahasa inggris. Dilihat dari indikator keberhasilan penggunaan aplikasi tersebut dan analisis jenis ekspresi ujaran emotif yang muncul sebelum kegiatan berlansung yaitu siswa-siswa sulit untuk mejawab pertanyaan yang diberikan oleh aplikasi tersebut dan penggunaan ekspresi bahasa inggris tertentu dalam konteks berinteraksi. Sedangkan, pencapaian setelah kegiatan adalah siswa mampu dengan baik memeberikan respon dari pertanyaan yang diajukan dengan struktur kata yang baik dan menggunakaan macam-macam espresi ujaran emotif dalam Bahasa inggris seperti empati, dukungan, simpati, dan lainlain.

\section{SIMPULAN}

Saat ini, khususnya dalam era digital, manusia sudah sangat dekat dengan transformasi yang terjadi dalam bidang informasi teknologi. Segala kegiatan dapat dilakukan dalam dunia maya, seringkali manusia memiliki keterbatasan untuk melakukan interaksi dengan sesama manusia lainnya secara langsung. Anak-anak, kawula muda, serta orang tua tampak sibuk dengan alat komunikasi digital mereka, karena keseharian aktivitas dapat dilakukan melalui gawai tersebut. Manusia seringkali tidak menyadari bahwa kebutuhan akan interaksi dengan manusia, untuk saling berkomunikasi, sangatlah penting dan signifikan untuk semua kalangan usia. Untuk memenuhi kebutuhan ini, muncullah berbagai aplikasi chatbot antara lain yang cukup dikenal adalah Replika. Replika dibangun dengan teknologi kecerdasan buatan yang mempelajari obrolan dengan pengguna sehingga mampu menyesuaikan dengan kepribadian pengguna.

Menyikapi hal ini maka edukasi bagaimana menggunakan dan memanfaatkan aplikasi ini dilakukan pada sekolah di Jatinangor sebagai yang mewakili dari kasus ini. Dalam menentukan keberhasilan dan pengetahuan dari remaja maka alat ukur yang digunakan adalah pengadaan kuis dan diikutsertakannya siswa-siswi dalaminteraksi bersama Replika. Dari hasil yang di dapatkan pada sekolah SMAN 1 Jatinangor sudah memahami bagaimana menggunakan aplikasi Replika dan bagaimana memanfaatkan Replika untuk meningkatkan kemampuan berbahasa Inggris mereka serta pemahaman ekspresi ujuran emotif dalam Bahasa inggris sehingga mereka dapa meimplemnetasikan dalam interaksi seharihari. 


\section{UCAPAN TERIMA KASIH}

Penulis mengucapkan terima kasih yang sebesarbesarnya dan penghargaan yang setinggitingginya kepada Rektor Universitas Padjadjaran, Direktur Riset, Pengabdian, dan Inovasi Unpad, Dekan Fakultas Ilmu Budaya Unpad dan semua pihak yang telah membantu dalam proses penelitian ini.

\section{DAFTAR PUSTAKA}

Djadjasudarma, F. (1993). Metode Linguistik: Ancangan Metode Penelitian dan Kajian. Jakarta: Refika Aditama.

Herring, S., Stein,D., \& Virtanen, T.(2013).Pragmatics of Computer-Mediated Communication. Walter de Gruyter.

Huang, Y. (2014). Pragmatics. Oxford University Press.

Levinson, S. C., S, L., \& Levinson, S. C. (1983). Pragmatics. Cambridge University Press.

Picard, R. W. (2000). Affective Computing. MIT Press. 